\title{
Recognition Of Prior Learning: Its Relevance To The Proposed Unified Model Of Education And Training For South African Nurses.
}

To an adult, his experience is him. He defines who he is, establishes his self-identity, in terms of a unique series of experiences... he has a deep investment in the value of his experience. And so, when he finds himself in a situation in whith his cxperience is not being used, or its worth is minimized, it is not just his experience that is being rejected. (Keaton, 1978).

T Khanyile University of Natal

\section{Research Article}

\section{Abstract}

Recognition of Prior Learning ( $R \mathrm{P} L$ ) is a fairly new concept in South Africa, and hence different people have different views about $\mathrm{R} \mathrm{PL}$. Through this paper, an attempt is made to shed some light on the historical background as well as the philosophical and theoretical underpinnings of $R \mathrm{PL}$. It is hoped that this information will help those nurse educators wishing to experiment with $R P L$ to have a better understanding of how the concept came about. The relevance of $R P L$ to the Unified model of nurse training proposed by the South African Nursing Council is also discussed.

\section{Abstrak}

Alhoewel die erkenning van vorige Leerervaring redelik nuwe konsep in Suid- Afrika is, het verskillende mense verskillende sieninge van die konsep Erkennimng van Vorige Leerervaring. Hierdie artikel is ' $n$ poging om meer lig op die histories agtergrond assok op die filasofiese en tearetiese begrondinge van Erkenning van Vorige Leerervaaring te werp. Hopenlike sal hierdie inligting verlpeegdanste wat met Erkenning van Vorige Leerervaaring wil eksperimenteer behulpsaam wees met die begrip van hoe die loonsep ontstaan het. Die belong van Erkenning van Vorige Leerervaaring in die algemene model van verpleegopleiding in Suid -Afrikaanse Raad op avaerpleeing, word ook bespreek.

\section{Introduction}

When one looks at the developments in Nursing Education in our country, it becomes evident that for the past century nursing education failed to offer nurses opportunities to progress from a nursing school to a college without duplication and extension in the period of training, or from a college to a university/ technikons since courses offered at all these institutions did not link up within institutions. A community health nurse who worked for more than ten years in a community health setting may have accumulated enough experience and may have learned from that experience, but the present system of training is such that whatever she/ he has learned cannot be recognised since there are no nationally approved mechanisms for this. This demotivated nurses who were eager to continue with their education since their prior learning experience is not recognised. Matric entrance requirement poses another problem. A number of people with a vast amount of previ- ous experience have been denied access on the basis that they did not possess Matric. Enrolled nurses wishing to do the Bridging programme for professional nurses have been turned down if they were not in possession of a Matric certificate. Nurses who have done the diploma programme before Matric was made an entry requirement, if they wish to register for a degree in nursing have to undergo a process of exemption on the basis of their age and not on the basis of their experience in nursing. What this means is that the present system of training does not recognise previous experience.

Nursing as a profession like many other professions finds itself at cross roads. Improving access for education and training in health sciences for groups previously disadvantaged by poor schooling or by virtue of race, gender or financial circumstances, is an urgent challenge. For nursing education, this necessitates a review of student selec- 
tion and the admission criteria. It also necessitates upgrading programmes for the enrolled nurse and the enrolled nurse assistant category.

The Health Science Working Group (1996), recommended that, in order to enhance mobility, provision should be made for multiple entry and exit points within the horizontally and vertically integrated system of education and training for health professionals through the development within the sector of a $\mathrm{Na}$ tional Qualification Framework principles. These recommendations are more relevarit to nursing education because improving access will mean unifying the education and training system of nurses so that enrolled nurses can for the first time be allowed to enter into the basic programmes without duplication and unnecessary extension of their training. It would appear therefore that the South African Nursing Councils' proposed Unified System of education and training for nurses was an outgrowth of the above proposals. According to the Nursing Council, the proposed system is a four year programme, the aim of which is the preparation of a professional nurse, capable of independent comprehensive practice. Thus there will be no shorter programmes similar to the current enrollment programmes ( South African Nursing Council S 1455, 1996 ). For the first time in the South African nurses history all trained nurses will be able to function independently, since they will all be comprehensively trained. The proposed unified system will allow for flexibility so that students can enter and exit at relevant levels according to their qualifications. This system will place nursing education in line with the National Qualifications Framework since principles like access, potability of credits and progression within the system will be possible. The first two years of the programme will allow candidates to exit as generic nurses with knowledge and skills in nursing, to plan and execute care plans. It is proposed that this nurse will be able to function independently at this level unlike the enrolled nurse of the previous two year programme. During the third and fourth year, the focus will shift to management skills of comprehensive patient care including the various disciplines ( midwifery, community, mental health). On completion, the student will be registered as a comprehensive generalist nurse( South African Nursing Council 1996). The most appropriate approach to the implementation of the National Qualifications Framework is through the system of Recognition of Prior Learning ( $R \mathrm{P} \mathrm{L}$ ). Therefore, for the transformation of Nursing Education and Training, R P L will be an appropriate approach. For potential candidates without matric but with previous relevant experience from say, voluntary or community work, they will be able to access the training programmes and hence widening the entry portal, unlike in the past where these candidates would be redirected to the enrolled programme. Those who already hold a qualification for example, enrolled nurse, they will be able to progress through in the unified system, and for the first time be allowed to proceed in the four year programme without extension or duplication. Recognition of their prior learning experience will be possible since they will be allowed to challenge the examination or submit evidence in the form of a portfolio to make a claim for previous experiential learning towards a particular qualification they do not hold. Seemingly, the SANC has taken the initiative in recognizing RPL as a vehicle for transformation of Nursing Education and Training in South Africa. Early this year SANC came to a resolution among others that: The present enrolled nurses and enrolled nursing auxilliaries should access into the 4 year comprehensive diploma/ degree programme using the principles of Recognition of Prior Learning (RPL) ( South Africa Nursing Council 2000 Doc).

However, like SAQA and the NQF, the South African Nursing Council has only made resolutions about RPL. Therefore, nurse educators need to explore the concept further, engage in more research into issues like how credits should be awarded without compromising standards. Instead of being excited by the notion of Recognition of Prior Learning, nurse educators need to ponder on these issues, so that problems experienced in other countries that experimented with RPL will be avoided.

\section{Purpose of this Paper}

The purpose of this paper is to explore the concept further, by tracing the history, its philosophical and theoretical underpinnings so that a more contextual understanding can be gained before the concept is experimented with in our profession.

\section{Prior Experiential Learning}

Experiential learning refers to learning in which the learner is directly in touch with the realities being studied. It is in contrast with learning in which the learner only reads about, hears about, talks about or writes about these realities, but never come into contact with them as part of the learning process (Keeton and Tate 1990: 67).

Recognition of Prior Experiential Learning therefore is a process that enables people to receive formal recognition for skills and knowledge they already possess. Since prior learning cannot be recognised before it has been assessed and because not all prior experience leads to learning, it is important for educators to carefully design mechanisms to identify, verify and assess prior learning before accreditation can be given. It is important also to highlight the fact that it is not how or where learning has occurred but the emphasis is on the outcomes of that learning. Therefore the National Qualifications Framework provides a vehicle for Recognition of Prior Learning. Through the standardisation of units of learning it is possible to verify learning against set criteria that describe the learning outcome.

According to Phillips (1997), there are two kinds of experiential learning. There is what is termed sponsored experiential learning and prior experiential learning namely:

- $\quad$ Sponsored experiential learning entails planned fieldwork or prac tical work which takes place outside the classroom but which forms part of the programme. This experiential learning is supervised by the teacher.

- Prior experiential learning is learning which includes both intentional learning, such as self- directed learning or non credit courses and incidental learning, from paid or unpaid work as well as other life experiences.

When we talk about recognition of experiential learning it is the second type of learning that is being referred to. A program for Recognition of Prior Experiential Learning would be a program structure with its own administrators and counsellors whose objective are to help candidates who present themselves for assessment with a view to either accreditation towards a qualification or exemption from a programme or a particular aspect of the programme (Ekstrom 1983: 125).

The method used for $R \mathrm{PL}$ is based on the following propositions:

- RPL means recognition of learning acquired through experience but not experience by itself. In other words, the candidate will have to provide evidence of learning from that particular experience. What is evaluated is the result of experience and not the amount of that experience. RPL is not an end in itself but a means towards an end since it is always done in relation to an objective, which is either to study further or employment or for promotion purposes. Therefore, it is necessary for the people involved with $R P L$ to carefully consider the objective/ purpose of the 
RPL programme so as to be able to select the assessment methods suitable for the purpose. RPL must respect the autonomy of the institution, the quality of their work and the dignity of the person who requests evaluation. RPL should ensure the transfer ability and the portability of cred its from diverse institutions and employment settings (Ekstrom 1983:131).

The choice of the method used for R P $L$ should be based on the above propositions.

\section{Brief History of Recognition of Prior Learning}

In America, official recognition of prior learning dates back as far as 1970's. It started in after the Second World War when the American soldiers who were returning from war requested that the skills they have learnt during their military service and the courses they followed to be able to perform their various tasks be taken into account in order to avoid duplication of learning. For the first time the Armed Force, the State colleges and universities, community groups, as well as industry got together in order to find possible ways to recognise the experiential learning of these people. Later on the adult population in general, following numerous social changes wanted to return to school and obtain credits for what they already knew. Women in particular felt that they needed recognition for all the voluntary services they offered as contribution to society. According to Stanley (1980), more than 300 institutions and hundreds of individuals contributed through research to improvement of practices which led to accreditation of prior learning.

Due to the growing demand for the recognition of prior learning, the Council for the Advancement of Experiential Learning ( CAEL ) was formed. It started as a small association of universities, colleges, groups of professionals in higher education who worked together for the advancement of the use of experiential learning in college and university education and for its valid and reliable assessments (Morris and Keaton 1985). This centre is located in New Jersey. Since then, C A E L has been active in initiating, developing, implementing and monitoring progress of the R P L systems across the U S A. Its memberships includes 600 colleges, universities, corporations, unions associations and individuals. The New York State College (1983); the Vermont State College (1978) and Thomas A. Edison College (1981), have all been active in implementing the system.

In the United Kingdom, with the help from the $C A E L$ the university colleges or polytechnics, concerned with helping adults in recognising their prior learning experiences started with $\mathrm{R} P \mathrm{~L}$ courses. In 1986, the Learning from Experience Trust was established. This was similar to the USA's CAEL since it was also an independent charity with social learning orientation aiming at developing ways in which people could make maximum benefit of their experiential learning. The Learning from Experience Trust (LET) undertakes research and development work and acts as a catalyst for changes within the mainstream of post secondary education and training systems (Simosko, 1991:96).

Other countries like Australia New Zealand and Canada have also been implementing the R P L system.

\section{South African Experiences with RPL}

As in the U S A, the need for R P L in South Africa was a labour market initiative. According to Harris (1994), formal work on R P L began in June 1994 when the National Training Board (N T B) established a sub- committee of an existing working group to address assessment issues. Prior to this point there were various initiatives at national and local levels, although they did not officially call them RP L systems. In terms of the current political ,economic and social context in South Africa, R P L is seen to have the capacity to contribute to redress and equity by opening up more inclusive ways for people to attain qualification status; it also enables more people to reach higher levels of qualification and expertise.

In South Africa while the Labour sector approach and understand the N Q F from the social and political perspective, the Education and Training sector is challenged by the need to redefine traditional boundaries between the academic, the professional and the vocational as well as the boundaries between formal ,non- formal and informal education (Harris 1997:45).

This Recognition of Prior Learning (RPL) for educators in South Africa is regarded as an official policy imperative and an administrative dilemma. At the level of policy, $\mathrm{R} P \mathrm{~L}$ is a key principle of the $\mathrm{Na}$ tional Qualifications Framework to be pursued across sectors. At delivery level it presents complex challenges (Musker 1998:8). The education system has been recognising prior learning in the past through the Joint Matriculation Board which has been issuing mature adults with certificates based on the notion that learning may take place outside an education system and that people learn through experience. What seems different now is that this Recognition of Prior Learning has been seen as a vehicle for redress. It has been perceived differently by different people in different contexts. For instance, from the Labour sector it is seen as a means for accreditation and hence increasing chances of employment. From the academic sector it is perceived as ensuring development and progression. It is these conflicting views about $R \mathrm{P} L$ that have led educators to be more concerned than excited with this innovation. There are concerns about lack of research on how effective these changes have been, in other words how comparable were graduates who obtained qualifications through processes like Recognition of Prior Learning in the business world? There are questions about how standards will be maintained during the implementation of such systems. There are questions from academics about Recognition of Prior Learning and compromising the value of an academic institution, such as development of critical thinking (Gawe 1999:5). Therefore it is these questions that nurse educators need to explore further.

\section{Philosophical Underpinnings of the RPL System}

According to Dewey, as cited in Tanner and Tanner (1980), one cannot penetrate very deeply into any significant educational problems or issues without encountering philosophical considerations (Tanner and Tanner 1980). This is also true of Recognition of Prior Learning, as this would shed more clarity on the meaning of the concept.

The intrinsic tendency for people to draw upon their own experiences for both knowledge and skills, and the vast accumulation of experience that an adult has, compared to a child, makes learner experience an important concept in adult education theory and practice. Although the experiential learning movement is not restricted tc adult education, it has always found a very comfortable location there. Saddington cited in Harris (1997), analysed the place of experience within the various traditions of adult education and through 'mapping' process addressed the place of adult experience within those traditions which are discussed below.

\section{Humanist tradition}

In this tradition, experience is the source of knowledge and the content of the curriculum. As the learner reflects on his/ 
her own experience so he/she takes possession of it in a new way and gains knowledge which is authentic because it is true for his/her life world. The possession of experience is a personal discovery of knowledge which enables the learner to become a complete person and hence self actualisation takes place (Harris 1997:34). This tradition is individual focussed and is not oriented to social change though the individual as a learner is expected to function within a given social context through increased levels of personal empowerment.

\section{Progressive tradition}

The progressive tradition in adult education grew out of a reaction to liberal education in an attempt to respond to the social and political changes in the twentieth century. The emphasis of education was changed from the intellectual development of the mind to a focus on individuals having a responsibility towards the society in which they lived. Education was seen as an instrument of social and political reform, which had a major role to play in the maintenance and extension of democracy. The progressive tradition sees education as lifelong and therefore learning how to learn is important for the learner then to continue to use both the knowledge that she gains from experience as well as knowledge that she gains from other resources like books, in solving problems and bringing about social change. The centrality of human experience in the progressive tradition means that the learner's experience is highly valued and is at last equal to the experience of others stored away in written word ( Tanner,. and Tanner, 1980:102). It becomes clear that the role of previous experience is highly valued by this tradition, and the fact that the most of the deliberations by the Department of Education and Training were influenced by this philosophy. This is also confirmed by the National Commission on Higher Education and Training' statement that:

The education system needs to be responsive to the social, cultural, political, and economic challenges in the country. Higher education institutions should therefore commit themselves in producing a workforce with the skills that the country needs. This is education for relevance. To ensure this, governance structures will have to provide stake holders consultation and participation dect sion making process (NCHE Report 1996:24).

\section{Reconstructionist}

This tradition has features in common with progressivism. The proponents of this philosophical thought betieve that human experience is culturally and historically determined. One's goals are grounded in experience and values are attached to goals. According to these philosophers, learning occurs directly through one's experience and indirectly through the experience of others (Brameld, 1986:67). For them education is the key to all societal reform. The curriculum must be geared to the transformation of the rising generation so that they embrace the goals and develop the needed means for collective social transformation (Tanner and Tanner, 1980:132). According to this philosophy, learning should not be confined to schools only, in other words other sites of learning like workplace should be recognised. This is enshrined in the National Qualifications Framework of the country. This tradition embraces democracy as the appropriate goal of education and therefore is in line with the ideologies of the Department of Labour which see learning as a tool for participation, transformation, democracy and taking control of own lives. The South African Qualifications Authority speaks about building a ' working democracy' in the postapartheid South Africa, therefore learning must transform society ( COSATU 1996: 32)

\section{Technological tradition}

In this tradition, value is accorded to experience to the extent that it matches skills and knowledge which has been prescribed according to national economic needs. Individual experience is always quantified and used to determine an appropriate entry point into educational or training system. Supported by the human capital theory, education in this tradition becomes increasingly instrumental, utilitarian and pragmatic. In other words, education becomes valued in terms of its usefulness to the labour market as well as the economic returns on investments in human capital. There is an emphasis on ensuring that people are able to adopt and fit into both organisational and societal goals. Thus the economic needs are more important than the individual needs. It is this tradition that has underpinned most established forms of vocational education and training internationally (Harris 1997: 43).

\section{Theoretical}

Underpinnings of RPL.

Experiential learning is a concept that is
as old as mankind, because individuals have always learned through trial and error, that is from tentative experiments conducted for the purpose of reaching a specific goal. What is often called learning by doing has been integrated into course offered in universities all over the world. The belief was that, continuous exposure to practice would allow the student to apply the learning acquired from theory. The experiential learning movement originated in the $U S A$, in the radical and liberal critiques of traditional education in the 1960s. According to Keeton and Tate (1990), experiential learning refers to learning in which the learner is in direct contact with the realities being studied. It is in contrast with learning in which the learner only reads about, talks about or writes about these realities, but never comes into contact with them as part of the learning process (Keeton and Tate, 1990).

Therefore, recognition of prior learning has been based on the experiential learning theory because new challenges for social justice and equal opportunities in higher education are based on the notion that people do learn from experience and the result of that learning can be assessed and certified at college level. Experiential learning theory offers a foundation for social policy and action since it can be used as a basis for constructive efforts to promote access to those who have been previously denied such access. In his own words, Kolb believes that:

"Experiential learning offers a theory of learning most appropriate for the assessment of prior learning and for the design of competence-centred curricula. Life long learning programs can find in experiential learning theory, a conceptual rationale and guiding philosophy as well as practical educational tools" Kolb 1984:216).

The proponents of experiential learning theory were concerned about the 'how' of learning since their focus was on adaptation as the central role of affective experience. However, the influence that this theory had on higher education as well as on labour organisations was such that these institutions realised that they had a responsibility for ensuring life long learning.

The experiential learning theoretical model was used by the Co operative Assessment of Experiential Learning (CAEL) project to create and implement practical and valid assessment methodologies for assessing what people have learned from prior work and life experiences. Researchers in this area were however more interested in what people have learned than in how they have learned. In other words, the emphasis was on the outcome of learning. This emphasis on outcomes within experiential learning led to the creation of formal links between education and industry since the linkage depended on accurate identification and matching of personal skills with program /job demands. According to Willingham (1977), 
the great significance of systemic recognition of prior learning is the linkage it provides between formal and adult life; that is a mechanism for integrating education and work, for recognising the validity of all learning that is relevant to a college degree and for actively fostering recurrent education (Willingham 1977:95).

According to Schon (1988), reflecting on experience enables its meaning to be grasped and its potential for future practice to be explored. People may reflect on action, by thinking back on what they have done in order to discover how their knowing -in- action may have contributed to an unexpected outcome (Schon 1988: 67 ). Evans (1987), discussed the relevance of experiential learning to $R P$ $L$ by identifying the characteristics of experiential learning and explaining how people become empowered through public recognition of their qualification after they have been through the Recognition of Prior Learning system and succeeded (Evans 1987: 36). Therefore, experiential learning theory can be used as basis for studies on R P L .

From the above discussions, it becomes evident that there are questions that need to be addressed by the Nursing Education system in order to meet the challenges of transformation of the education system for nurses that the SANC is proposing. Since nurses form more than $65 \%$ of the health sector, it becomes clear that transformation of their education system is an important part of transforming health professional education. There is a need for the following: unification of the training programmes with an aim of eliminating unnecessary duplication, and hence making programmes cost effective. There is also a need for the development of a system that will ensure that the backlog of nurses who were not comprehensively trained, are assimilated back into the education system to ensure their effective utilisation in primary and in district health settings where the need is greatest. Programmes for nurse training need to be structured in such a way that they are in line with the objectives of the $\mathrm{Na}$ tional Qualifications Framework, especially those that deal with progression, portability of credits. Lastly, research into methodologies to implement the NQF principles is necessary.

\section{Conclusion}

Developments in Nursing Education have historically been influenced by developments in the Education system of the country. Therefore it is important to trace developments within the general system of education, their implications on nursing education, and how the nurs- ing education stake holders are prepared to meet these challenges. The present National Education and Training system is currently engaged in a process of reconstruction and transformation so as to reflect an integrated approach which will address the learners and the country' needs.

The principles of the National Qualifications Framework namely: progression; relevance; access and portability need to be implemented in the education and training of nurses. The South African Nursing Council 's proposal for a unified system of education and training for nurses is a measure to ensure the implementation of these principles.

Through this paper, I have tried to highlight the relevance of the $R P L$ concept to the Unified model proposed by the South African Nursing Council. The historical background, and the meaning of the concept Recognition of Prior Learning has been discussed as well as the different traditions and the theoretical underpinnings of $\mathrm{R} P \mathrm{~L}$. One can conclude therefore that the perspective, the purpose and the approaches used for the Recognition of Prior Learning systems will be influenced by one or a combination of these traditions.

\section{Bibliography}

AMERICAN COUNCIL ON EDUCATION PROGRAMS ON COLLEGEIATE SPONSORED INSTRUCTION. Washington DC 20036.

BUTTERWORTHS, C., \& EDWARDS, R.1993.Open Learning. Assessment of prior learning.

COLEMAN, J.S. 1976. Differences between experiential and classroom learning. In M.T.

COMMITTEE OF UNIVERSITY PRINCIPALS (CUP). 1997. Macro- aspects of the university within the Context of Tertiary Education. Pretoria: CUP.

COMMUNITY COLLEGE OF VERMONT. 1978. Student Progress Portfolio. Montpelier, Vt,

EKSTROM, R.B.1983. Assessing prior learning experiences. San Fransisco: Jossey- Bass.

Empire State College. (1983). Student planning Guide for Degree Programs and portfolios. State University of New York, N. Y.

EVANS, N. 1990. Experiential Learning Relevance of Prior Learning. London: Sage Publications.

EVANS, N. 1992. Experiential Learning: Its assessment and Accreditation. London: UK Rouledge.

GAWE, N. 1999. Arming ourselves for recognition of prior learning. Paper presented at the South African Research and Development in Higher Education Conference.

GOVERNMENT NOTICE. 1996. Government Gazette, Volume Number 1455.

HARRIS, J. 1997. Recognition of Prior Learning ( $R \mathrm{PL}$ ) .Introducing a Conceptual Framework. University of Cape Town Press.

HUMAN SCIENCE RESEARCH COUNCIL.1995. Ways of seeing the national qualifications framework. Pretoria:HSRC.

KOLB, D.A.1984. Experiential Learning Experience as the Source of Learning and Development. Prentice Hall Inc., New Jersey.

KEATON, M. M., \& TATE, P 1990. New Directions for Experiential Learning: what next in experiential learning? Learning by experience, what, why, how. Number1. Jossey- Bass Inc., Carlifonia. 
KEATON. (Ed). 1978. Experiential Learning: Rationale, Characteristics and Assessment. San Fransisco: Jossey- Bass.

Le GOFF, J. 1994. White Paper on Education and Training. Teaching and learning : Towards a learning Society. Paris.

MATHEW, D. 1995. Outcomes Learning and the Curriculum. Outcomes in Management in

MUSKER, P. 1998. Who's afraid of RPL? Joint Education Bulletin. 8 (July) 8-10

NATIONAL COMMISSION ON HIGHER EDUCATION. 1996. A Framework for Transformation. Report. 124 of 1996). Pretoria: Department of Education.

NATIONAL COMMISSION ON HIGHER EDUCATION. 1997. Report Document. South Africa.

NATIONAL COMMISSION ON HIGHER EDUCATION. 1998. Health science working group [online]. South Africa: Pretoria. Available from: http://star.hsrc.ac.za/nche/health/2.html [Accessed 23 Feb 1999].

PHILLIPS, B. 1997. Getting to Grips with the National Qualifications Framework. Gauteng: NQF Network.

SANSREGRET, M. , EKSTROM, R.B. 1984. Awarding College Credit for women's non paid work. Paper presented at The Second International Interdisciplinary Congress, Croningen University' Netherlands.

SCHON, D. 1991. The Reflective Practitioner: How Professionals Think in ACtion.

SIMOSKO, S. 1985. Earn College Credit for What You Know. Washington: Acropolis Books, Ltd.

SOUTH AFRICAN NURSING COUNCIL. 1996. South African Nursing Council Record:S1455. Pretoria: SANC

SOUTH AFRICAN NURSING COUNCIL. 1997. A unified nursing education system for South Africa. Document int. 511/ 97. SANC.

SOUTH AFRICAN NURSING COUNCIL. 2000. Transformation of nursing education and training in South Africa. Pretoria: SANC.

SOUTH AFRICAN QUALIFICATIONS ACT (Number 58) 1995. Pretoria : South Africa.

South African Qualifications Authority (SAQA). 1998. The National Qualifica- tions Framework :A total Quality system for education and training in South Africa. SAQA.

TAFE. 1992. Assessing Competency at the Workplace. Summary Report, Department of Education, Employment and Training. Australia.

THOMAS, A. EDISON STATE COLLEGE. 1981. Earning College Credit for what you know. Trenton: New York.

TUNNER D. AND TUNNER, L.N.1980. Curriculum development, theory into practice. New York: Mc Millan Publishers.

VALLA, V.1998. Enterpreneurial training for youth. Joint Education Trust Bulletin. 8(July) $8-10$

WILLINGHAM, W.W. 1977. Principles of good practice in Assessing Experiential Learning, CAEL. 